\title{
IN VITRO CYTOTOXIC ANTICANCER POTENTIAL OF BIOACTIVE FRACTION ISOLATED FROM INDONESIAN TIDAL SPONGE CALTHROPELLA SP.
}

\author{
FITRIA SUSILOWATI ${ }^{1}$, RESPATI TRI SWASONO ${ }^{1 *}$, TATSUFUMI OKINO ${ }^{2}$, WINARTO HARYADI ${ }^{1}$
}

\author{
${ }^{1}$ Department of Chemistry, Universitas Gadjah Mada, Yogyakarta, Indonesia, ${ }^{2}$ Department of Graduate School of Environmental \\ Sciences, Hokkaido University, Sapporo, Japan. Email: respati@ugm.ac.id
}

Received: 14 November 2018, Revised and Accepted: 24 November 2018

\section{ABSTRACT}

Objective: This study was taken to examine the cytotoxicity of the bioactive fraction isolated from marine sponge Calthropella sp. as a preliminary anticancer assay and identify its bioactive compounds.

Methods: The cytotoxic activity was assessed by 3-(4,5-dimethylthiazol-2-y1)-2,5-diphenyltetrazolium bromide assay against three human cancer cell lines, namely human breast (MCF-7), human lung (H-460), and human liver (HepG-2). The bioactive compounds were identified using a high-resolution liquid chromatography-mass spectroscopy (LC-MS).

Results: The active fraction 7 showed moderate to strong cytotoxic activity on all cell lines tested and promising a strong potent cytotoxicity against MCF-7 cell lines with IC $_{50}$ value as low as $1.925 \mu \mathrm{g} / \mathrm{mL}$ comparable to control, cisplatin ( $\mathrm{IC}_{50} 0.977 \mu \mathrm{g} / \mathrm{mL}$ ). In regard to the promising bioactive compounds, the high-resolution LC-MS predicted the existing of several known compounds such as bengamide Q, clavepictine A, 4'-N-methyl-5'hydroxystaurosporine, carteriofenone A, and one strong possibility of a new compound.

Conclusion: This study has revealed that the isolated bioactive fraction of Indonesian tidal sponge, Calthropella sp., possesses potential anticancer properties with a promising significant cytotoxicity on MCF-7 cell lines ( IC $\left._{50} 1.925 \mu \mathrm{g} / \mathrm{mL}\right)$.

Keywords: Calthropella sp., 3-(4,5-Dimethylthiazol-2-y1)-2,5-diphenyltetrazolium bromide assay, MCF-7, H-460, HepG-2.

(c) 2019 The Authors. Published by Innovare Academic Sciences Pvt Ltd. This is an open access article under the CC BY license (http://creativecommons. org/licenses/by/4. 0/) DOI: http://dx.doi.org/10.22159/ajpcr.2019.v12i1.23655

\section{INTRODUCTION}

Cancer is a leading cause of deaths worldwide, accounting for approximately 7.6 million deaths (13\% of all deaths) in 2008. The WHO predicted that cancer mortality will increase up to 11 million deaths in 2030 [1]. In Indonesia, cancer becomes the seventh leading cause of death (5.7\%), with the prevalence of $1.4 / 1000$ populations or equal to 347 thousand of people [2]. This growing trend indicates deficiency in the present cancer therapies; moreover, the increasing number of multidrug-resistance had worsened the situation [3]. In this context, natural products derived have gained significance interest in the treatment of cancer.

In the past decades, a dramatic increase in the number of preclinical anticancer lead compounds from diverse marine life enters human clinical trials [4-6]. Among thousands of marine organism, sponges, in particular, are responsible for $>30 \%$ isolated potent compounds from marine origin [7]. Marine sponges continue to attract wider attention in the way of discovery attempt for new natural leads of anticancer candidates.

Cytotoxicity has been defined as the cell killing property of a chemical compound independent from the mechanism of death [8]. Cytotoxic assay is an appropriate method for screening new substances within a short time to determine cytotoxicity on cancer cells [9]. In oncology research and clinical practices, in vitro testing is preferred before in vivo testing. In vitro methods like 3-(4,5-dimethylthiazol-2-y1)-2,5diphenyltetrazolium bromide (MTT) assay have been described as rapid, simple, and reproducible method, widely used in the screening of anticancer drugs and to measure the cytotoxic properties. The assay is based on the capacity of mitochondrial dehydrogenase enzymes in living cells to convert the yellow water-soluble substrate MTT into a dark blue water-insoluble formazan. This formation production is proportionate to the viable cell number and inversely proportional to the degree of cytotoxicity.

Our present purpose is to assess the in vitro cytotoxic anticancer activity of bioactive fractions of Indonesian tidal sponge Calthropella sp. on the three human cancer cell lines, namely breast adenocarcinoma (MCF-7), hepatocellular carcinoma (HepG-2), and lung carcinoma (H-460). The active fraction was then analyzed by high-resolution liquid chromatographymass spectroscopy (LC-MS) to predict the bioactive compounds.

\section{MATERIALS AND METHODS}

\section{Materials}

The sample used was fresh marine sponge Calthropella sp. The solvent used for general purposes were commercial grade; Merck proanalysis solvent, for example, hexane, dichloromethane (DCM), ethyl acetate (EtOAc), methanol $(\mathrm{MeOH})$, high-performance liquid chromatography (HPLC)-grade acetonitrile (MeCN), and formic acid (FA). The flash column chromatography was done using silica gel $60(0.040-0.063 \mathrm{~mm})$. Thin-layer chromatography (TLC) was performed on silica gel 60 $\mathrm{F}_{254}(0.20 \mathrm{~mm}$ thickness $)$. The in vitro preliminary MTT cytotoxic assay was carried out with Roswell Park Memorial Institute (RPMI-1640), Wako cell medium, fetal bovine serum (FBS) BioWest, trypan blue, dimethyl sulfoxide (DMSO), Dulbecco's phosphate-buffered saline Biochrom, ethanol, trypsin-ethylenediaminetetraacetic acid, cisplatin (Sigma-Aldrich), and MTT reagent (Sigma). Three human cancer cell lines were used: MCF-7 breast adenocarcinoma cancer cells (ECACC), H-460 lung cancer cells (ATCC HTB-177, Summit Pharma), and hepatocellular carcinoma liver cancer cells, HepG-2 (ATCC, HB-8065).

\section{Instrumentations}

Analytical balance (Nettler Toledo AB204-S), Ultrasonic bath SIBATA, Rotavapor B-720 Büchi, CAMAG UV lamp (254 and $366 \mathrm{~nm}$ ), vortex 
mixer (Thermoline), centrifuge (Himac CR'5B HITACHI), autoclave, incubator with $5 \% \mathrm{CO}_{2}$ humidity at $37^{\circ} \mathrm{C}$ (Memmert), microscope (Olympus CX-3), TC-10 automated cell counter (BioRad), and Thermo Labsystems Multiskan JX microplate reader were used.

\section{Sample collection}

The sea sponge Calthropella sp. was collected by handpicking during low tide from Krakal Beach, Gunungkidul ( $8^{\circ} 8^{\prime} 42.66^{\prime \prime} \mathrm{N}$ and $110^{\circ} 36^{\prime}$ $3.15^{\prime \prime} \mathrm{E}$ ), on August 2015. The sponges were kept frozen from collection until the extraction process. The marine sponge Calthropella sp. had earlier been identified at the Laboratory of Animal Taxonomy, Faculty of Biology, Universitas Gadjah Mada.

\section{Extraction and isolation}

The frozen sponge ( $0.8 \mathrm{~kg}$, total) was cut and macerated with a mixture of solvent $\mathrm{MeOH} / \mathrm{DCM}(1: 2, \mathrm{v} / \mathrm{v})$. The two layers were separated using a separatory funnel, and DCM layer was concentrated under reduced pressure. DCM extract was then partitioned between EtOAc/ $\mathrm{H}_{2} \mathrm{O}$ $(3: 2, v / v)$. The interesting EtOAc layer was dried and evaporated to yield a viscous extract of EtOAc. EtOAc extract was then fractionated by flash column chromatography (Si gel 60) by stepped gradient elution. The hexane, EtOAc, and $\mathrm{MeOH}$ were added to enhance polarity [10]. The elution was driven through the column by applying pressure. Fractions of a standard volume were collected and then combined based on the spots similarity using TLC. The resulted fractions were then concentrated under reduced pressure.

\section{In vitro MTT cytotoxic assay}

A standard MTT assay was performed based on the method reported by Mosmann [11]. Briefly, MCF-7, H-460 lung, and HepG-2 were maintained in RPMI- 1640 medium with $10 \%$ FBS. Cancer cells were seeded into 96-well plates at a density of $1.0 \times 10^{4}$ cells per well. After $24 \mathrm{~h}$ at $37^{\circ} \mathrm{C}$ with $5 \% \mathrm{CO}_{2}$, the cells were treated with sample solutions containing different concentrations of the test material and incubated for $72 \mathrm{~h}$ under the same conditions. The medium was removed and replaced with $100 \mu \mathrm{L}$ of MTT in RPMI- 1640 with $10 \%$ FBS $(0.5 \mathrm{mg} / \mathrm{mL})$, and the cells were then incubated for $3 \mathrm{~h}$ at $37^{\circ} \mathrm{C}$ with $5 \% \mathrm{CO}_{2}$. MTT solution was aspirated, and the formazan crystals were dissolved in DMSO. After 10 min of incubation, the optical density at $570 \mathrm{~nm}$ was measured. Cisplatin was used as the positive control.

\section{Compounds identification by LC-MS analysis}

LC-MS analysis was conducted on an Agilent 1100 Series HPLC system coupled with a Bruker Daltonics micrOTOF-HS mass spectrometer (ESI). HPLC system was equipped with a Cadenza CD-C18 column $\left(2 \times 150 \mathrm{~mm}, 3 \mu \mathrm{m}, 25^{\circ} \mathrm{C}, 0.2 \mathrm{~mL} / \mathrm{min}\right)$ under the following condition: 0-40 min, isocratic elution of $80 \% \mathrm{MeCN}$ with $0.1 \%$ (v/v) FA in $\mathrm{H}_{2} \mathrm{O}$.

\section{RESULTS AND DISCUSSION}

\section{Extraction and isolation}

EtOAc extract obtained ( $217.5 \mathrm{mg}$, weight) was yellowish-brown in color. The fractionation by column chromatography afforded eight fractions after combining the spots similarity based on TLC.

\section{Preliminary in vitro MTT cytotoxic assay}

The preliminary in vitro MTT cytotoxic assay was done to screen the most active fraction out of eight fractions. The MCF-7 cell lines were incubated for $72 \mathrm{~h}$ with the fractions at concentrations of 10 and $100 \mu \mathrm{g} / \mathrm{mL}$; then, the cell viability was assessed by MTT assay. Then, leads for further assay were selected on the fraction with highest inhibition, which is close to cisplatin as positive control.

Overall cytotoxicity varied between fractions, yet it exhibited concentration-dependent growth inhibition (Fig. 1). Of all fractions, maximum inhibition showed by the fraction 7 , satisfactory inhibited $90 \%$ and $100 \%$ at $10 \mu \mathrm{g} / \mathrm{mL}$ and $100 \mu \mathrm{g} / \mathrm{mL}$, respectively. Fraction 7 is considered for being potent as it showed least cell growth comparable to cisplatin at both concentrations tested. Therefore, fraction 7 was selected for further in vitro MTT cytotoxic assay at a wider range of

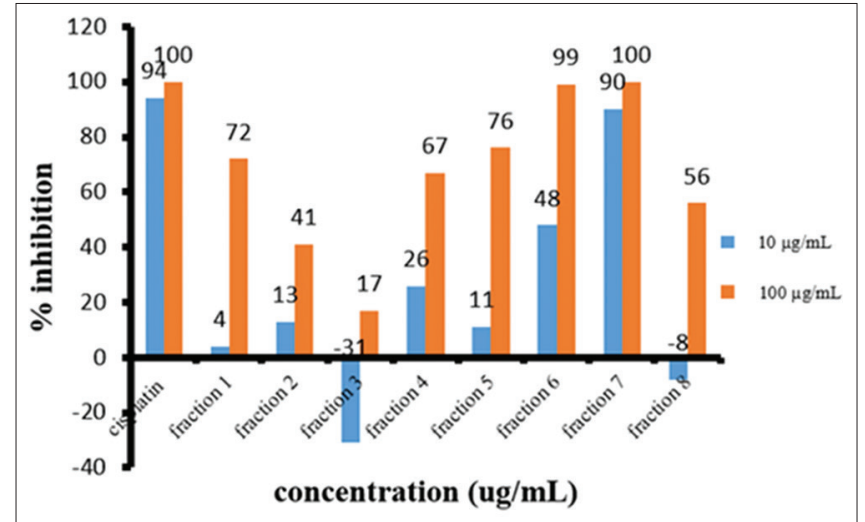

Fig. 1: Cytotoxic activity of ethyl acetate fractions on MCF-7 cells

Table 1: Comparative in vitro inhibitory activity of fraction 7 against selected carcinomas, with cisplatin as a positive control

\begin{tabular}{lll}
\hline Cell lines & \multicolumn{2}{l}{ IC $_{\mathbf{5 0}}$ values $(\boldsymbol{\mu g} / \mathbf{m L})$} \\
\cline { 2 - 3 } & Cisplatin & Fraction 7 \\
\hline MCF-7 (human breast) & 0.977 & 1.925 \\
H-460 (human lung) & 1.459 & 165.532 \\
HepG-2 (human liver) & 1.316 & 53.011 \\
\hline
\end{tabular}

concentrations to evaluate the $\mathrm{IC}_{50}$ value (concentration of the active fractions or cisplatin that inhibits the number of viable cells by $50 \%$ ).

\section{In vitro MTT cytotoxic assay of fraction 7}

Three human cancer cell lines (MCF-7, H-460, and HepG-2) were treated with the fraction 7 at a wider range of concentrations $(0.01-1000 \mu \mathrm{g} / \mathrm{mL})$ and then, cell viability was assessed by MTT assay. The presence of viable cells was visualized by the development of purple color due to the formation of formazan crystals. The $\mathrm{IC}_{50}$ for each cell line was determined using probit analysis with the help of the statistical program SPSS 22. The values of the $\mathrm{IC}_{50}$ are summarized in Table 1.

Cisplatin is one of the most effective synthetic anticancer agents widely used in the treatment of solid tumors. It is generally considered as a cytotoxic drug which kills cancer cells by damaging DNA. However, patients who initially respond to cisplatin therapy often develop resistance to the drug during the course of the treatment [3].

The results in cell growth inhibition by fraction 7 and cisplatin against the cell lines are shown in Fig. 2. A concentration-dependent manner could be observed in all cell lines tested. As the concentration increases, there is also an increase in the cell growth inhibition. Fraction 7 succeeded to inhibit $99 \%$ of MCF-7 cells with concentration of $100 \mu \mathrm{g} / \mathrm{mL}$. These data are of interest, as it suggests that fraction 7 showed potent cytotoxicity on MCF-7 with IC $1.925 \mu \mathrm{g} / \mathrm{mL}$ compared with cisplatin, $0.977 \mu \mathrm{g} / \mathrm{mL}$. As established by the American National Cancer Institute, the IC ${ }_{50}$ value is standardized $<30 \mu \mathrm{g} / \mathrm{mL}$ for anticancer agents, thereby fraction 7 is considered for being potent against MCF-7. In concern of H-460 and HepG-2 cells, the standard cisplatin showed consistently strong cytotoxic activity, with $\mathrm{IC}_{50}$ values of 1.459 and $1.316 \mu \mathrm{g} / \mathrm{mL}$, respectively. Contrarily, the percentage inhibitions of fraction 7 averagely decrease from that on MCF-7 cells. In this case, fraction 7 showed less significant cytotoxic activity toward $\mathrm{H}-460$ and HepG-2 cells. It is proved by the $\mathrm{IC}_{50}$ values which were found to be lesser than that on MCF-7 (165.532 and $53.011 \mu \mathrm{g} / \mathrm{mL}$, respectively, for H-460 and HepG-2).

Fraction 7 was then identified for the compounds by LC-MS analysis. The chromatogram separation result of fractions 7 shown in Fig. 3. Identification of the structure was done using literature study of marine natural product compounds, Lit [12], which has a similar structural 
Table 2: Compounds identification of fraction 7

\begin{tabular}{|c|c|c|c|c|}
\hline RT & $\begin{array}{l}\text { Measured } \\
\text { mass (amu) }\end{array}$ & $\begin{array}{l}\text { Molecular formula of } \\
\text { theoretical mass (amu) }\end{array}$ & Name of compound & Structure of compound \\
\hline 4.4 & $582.4256[\mathrm{M}]^{+}$ & $\mathrm{C}_{32} \mathrm{H}_{58} \mathrm{~N}_{2} \mathrm{O}_{7} 582.4244$ & Bengamide Q & \\
\hline 6.0 & $497.2316[\mathrm{M}+\mathrm{H}]^{+}$ & $\mathrm{C}_{28} \mathrm{H}_{29} \mathrm{~N}_{6} \mathrm{O}_{3} 497.2223$ & 4'-N-methyl-5'-hydroxystaurospo-rine & \\
\hline 7.0 & $348.2991[\mathrm{M}+\mathrm{H}]^{+}$ & $\mathrm{C}_{21} \mathrm{H}_{38} \mathrm{~N}_{3} \mathrm{O}_{3} 48.2991$ & Clavepictine A & \\
\hline 9.6 & $363.3193[\mathrm{M}+\mathrm{H}]^{+}$ & $\mathrm{C}_{20} \mathrm{H}_{38} \mathrm{~N}_{6} 363.3145$ & Biemnic acid & \\
\hline $\begin{array}{l}12.9 \\
13.6\end{array}$ & $\begin{array}{l}540.4622[\mathrm{M}+\mathrm{H}]^{+} \\
501.3893[\mathrm{M}+\mathrm{H}]^{+}\end{array}$ & $\begin{array}{l}\mathrm{C}_{32} \mathrm{H}_{62} \mathrm{NO}_{5} 539.4549 \\
\mathrm{C}_{33} \mathrm{H}_{48} \mathrm{~N}_{4} 500.3866\end{array}$ & $\begin{array}{l}\text { New compound } \\
\text { Carteriofenone A }\end{array}$ & \\
\hline
\end{tabular}

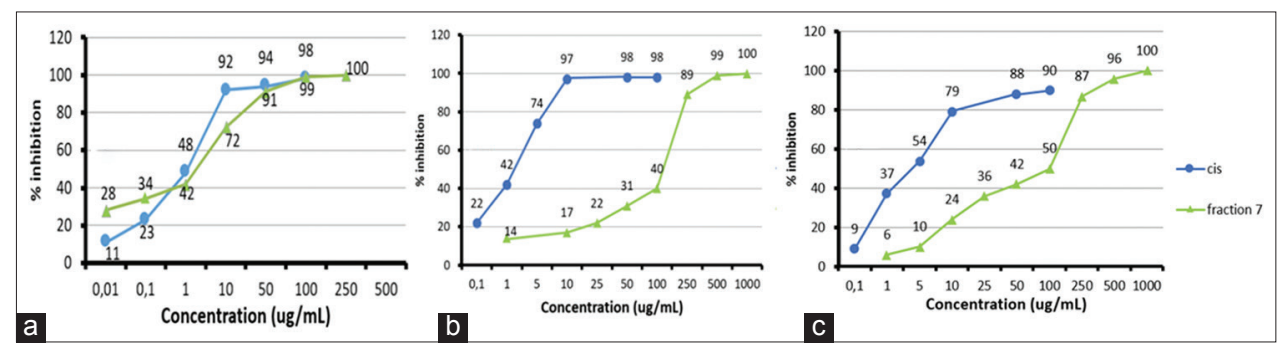

Fig. 2: Cytotoxic activity of the active fraction 7 at different concentrations against: (a) MCF-7, (b) H-460 cells, and (c) HepG-2 cells

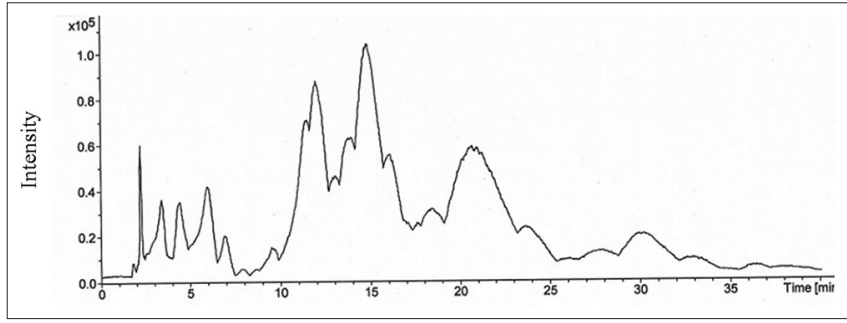

Fig. 3: Chromatogram liquid chromatography fraction 7 (Eluent 80\% MeCN: $20 \% \mathrm{H}_{2}$ O) formula and the closest molecular mass from MS spectra. The predicted existing compounds are shown in Table 2.

LC-MS analysis of the fraction 7 reveals that the sponge has components, mostly alkaloids (N-containing heterocycles: Bengamide Q, 4'-N-methyl-5'-hydroxystaurosporine, and clavepictine A). Those isolated compounds have been reported to have a high anticancer activity [13-15]. In regard to mechanism of action, several recent studies reported that alkaloids have the ability to promote apoptosis through inducing DNA damage [16-18]. Other isolated compounds can also be expected to contribute to the anticancer activity possessed by marine sponge Calthropella sp. 


\section{CONCLUSION}

EtOAc fraction of Indonesian tidal sponge, Calthropella sp., is considered as a bioactive fraction as it is exhibited an interesting cytotoxic anticancer potential. The active fraction 7 showed moderate to strong cytotoxic activity on MCF-7, H-460, and HepG-2 cell lines ( IC $_{50} 1.925,165.532$, and $53.011 \mu \mathrm{g} / \mathrm{mL}$, respectively). In addition, fraction 7 promises a strong potent cytotoxicity against MCF-7 cell lines with $\mathrm{IC}_{50}$ value as low as $1.925 \mu \mathrm{g} / \mathrm{mL}$ compared to cisplatin $\left(\mathrm{IC}_{50} 0.977 \mu \mathrm{g} / \mathrm{mL}\right)$. The high-resolution LC-MS revealed that fraction 7 predicted to contain mostly known bioactive compounds and one possibility of a new compound.

\section{ACKNOWLEDGMENT}

This study was conducted as part of Population-Activities-ResourcesEnvironment exchange program, Hokkaido University. We are grateful to Dr. M. Kurasaki, Head of Biochemistry Laboratory, Faculty of Environmental Earth Science, Hokkaido University, for providing access to their cell culture facilities.

\section{AUTHORS' CONTRIBUTIONS}

First author performed the procedure. Second, third, and fourth author guided through the procedure. All authors discussed and contributed to the final manuscript.

\section{CONFLICTS OF INTEREST}

All authors have none to declare.

\section{REFERENCES}

1. World Health Organization. Global Status Report on Noncommunicable Diseases. Switzerland: WHO Press; 2011. p. 176.

2. Indonesian Ministry of Health. Riset Kesehatan Dasar 2013 Badan Litbangkes Dan Data Penduduk Sasaran. Jakarta: Pusdatin Kementerian Kesehatan RI; 2014. p. 306.

3. Florea AM, Büsselberg D. Cisplatin as an anti-tumor drug: Cellular mechanisms of activity, drug resistance and induced side effects. Cancers (Basel) 2011;3:1351-71.

4. Blunt JW, Copp BR, Hu WP, Munro MH, Northcote PT, Prinsep MR, et al. Marine natural products. Nat Prod Rep 2009;26:170-244.

5. Simmons TL, Andrianasolo E, McPhail K, Flatt P, Gerwick WH. Marine natural products as anticancer drugs. Mol Cancer Ther 2005;4:333-42.

6. Molinski TF, Dalisay DS, Lievens SL, Saludes JP. Drug development from marine natural products. Nat Rev Drug Discov 2009;8:69-85.

7. Mehbub MF, Lei J, Franco C, Zhang W. Marine sponge derived natural products between 2001 and 2010: Trends and opportunities for discovery of bioactives. Mar Drugs 2014;12:4539-77.

8. Graham-Evans B, Tchounwou PB, Cohly HH. Cytotoxicity and proliferation studies with arsenic in established human cell lines: keratinocytes, melanocytes, dendritic cells, dermal fibroblasts, microvascular endothelial cells, monocytes and tcells. Int J Mol Sci 2003;4:13-21.

9. Alley MC, Scudiero DA, Monks A, Hursey ML, Czerwinski MJ, Fine DL, et al. Feasibility of drug screening with panels of human tumor cell lines using a microculture tetrazolium assay. Cancer Res 1988;48:589-601.

10. Susilawati S, Sabirin M, Harno DP, Chairil A. Antioxidant activity of 2,6,4'-trihydroxy-4-methoxy benzophenone from ethyl acetate extract of leaves of mahkota dewa (Phaleria macrocarpa (Scheff.) Boerl.). Indo J Chem 2011;11:180-5.

11. Mosmann T. Rapid colorimetric assay for cellular growth and survival: Application to proliferation and cytotoxicity assays. J Immunol Methods 1983;65:55-63.

12. Lit M. A Database of the Marine Natural Product Literature. Royal Society of Chemistry (UK). Available from: http://www.pubs.rsc.org/ marinlit/. [Last accessed on 2015 Nov???]

13. White KN, Tenney K, Crews P. The bengamides: A Mini-review of natural sources, analogues, biological properties, biosynthetic origins, and future prospects. J Nat Prod 2017;80:740-55.

14. Hernández LM, Blanco JA, Baz JP, Puentes JL, Millán FR, Vázquez FE, et al. 4'-N-methyl-5'-hydroxystaurosporine and 5'-hydroxystaurosporine, new indolocarbazole alkaloids from a marine Micromonospora sp. Strain. J Antibiot (Tokyo) 2000;53:895-902.

15. Raub MF, Cardellina JH $2^{\text {nd }}$, Choudhary MI, Ni CZ, Clardy J, Alley MC. Clavepictines A and B: Cytotoxic quinolizidines from the tunicate Clavelina picta. J Am Chem Soc 1991;113:3178.

16. Habli Z, Toumieh G, Fatfat M, Rahal ON, Gali-Muhtasib H. Emerging cytotoxic alkaloids in the battle against cancer: Overview of molecular mechanisms. Molecules 2017;22. pii: E250.

17. Ardiansah B. Recent reports on pyrazole-based bioactive compounds as candidate for anticancer agents. Asian J Pharm Clin Res 2017;10:45-51.

18. Ismail MM, Soliman DH, Farrag AM, Sabour R. Synthesis, antitumor activity, pharmacophore modelling and QSAR studies of novel pyrazolesand pyrazolo [1,5-a] pyrimidines against breast adenocarcinoma MCF-7 cell line. Int J Pharm Pharm Sci 2016;8:434-42. 